Article

\title{
Solvent-free selective oxidation of cyclohexane with molecular oxygen over manganese oxides: Effect of the calcination temperature
}

\author{
Mingzhou Wu, Wangcheng Zhan \#, Yun Guo, Yunsong Wang, Yanglong Guo, Xueqing Gong, Li Wang, \\ Guanzhong Lu* \\ Key Laboratory for Advanced Materials and Research Institute of Industrial Catalysis, East China University of Science and Technology, Shanghai 200237, \\ China
}

\section{A R T I C L E I N F O}

\section{Article history:}

Received 9 August 2015

Accepted 22 September 2015

Published 5 January 2016

\section{Keywords:}

Manganese oxide catalyst

Selective oxidation of cyclohexane

Oxygen

Calcination temperature

Solvent-free reaction

\begin{abstract}
A B S T R A C T
The effects of calcination temperature on the physicochemical properties of manganese oxide catalysts prepared by a precipitation method were assessed by X-ray diffraction, $\mathrm{N}_{2}$ adsorption-desorption, X-ray photoelectron spectroscopy, $\mathrm{H}_{2}$ temperature-programmed reduction, $\mathrm{O}_{2}$ temperature-programmed desorption, and thermogravimetry-differential analysis. The catalytic performance of each of these materials during the selective oxidation of cyclohexane with oxygen in a solvent-free system was subsequently examined. It was found that the $\mathrm{MnO}_{x}-500$ catalyst, calcined at $500{ }^{\circ} \mathrm{C}$, consisted of a $\mathrm{Mn}_{2} \mathrm{O}_{3}$ phase in addition to $\mathrm{Mn}_{5} \mathrm{O}_{8}$ and $\mathrm{Mn}_{3} \mathrm{O}_{4}$ phases and possessed a low surface area. Unlike $\mathrm{MnO}_{x}-500$, the $\mathrm{MnO}_{x}-400$ catalyst prepared at $400{ }^{\circ} \mathrm{C}$ was composed solely of $\mathrm{Mn}_{3} \mathrm{O}_{4}$ and $\mathrm{Mn}_{5} \mathrm{O}_{8}$ and had a higher surface area. The pronounced catalytic activity of this latter material for the oxidation of cyclohexene was determined to result from numerous factors, including a higher concentration of surface adsorbed oxygen, greater quantities of the surface $\mathrm{Mn}^{4+}$ ions that promote oxygen mobility and the extent of $\mathrm{O}_{2}$ adsorption and reducibility on the catalyst. The effects of various reaction conditions on the activity of the $\mathrm{MnO}_{x}-400$ during the oxidation of cyclohexane were also evaluated, such as the reaction temperature, reaction time, and initial oxygen pressure. Following a $4 \mathrm{~h}$ reaction at an initial $\mathrm{O}_{2}$ pressure of $0.5 \mathrm{MPa}$ and $140{ }^{\circ} \mathrm{C}$, an $8.0 \%$ cyclohexane conversion and $5.0 \%$ yield of cyclohexanol and cyclohexanone were achieved over the $\mathrm{MnO}_{x}-400$ catalyst. In contrast, employing $\mathrm{MnO}_{x}-500$ resulted in a $6.1 \%$ conversion of cyclohexane and $75 \%$ selectivity for cyclohexanol and cyclohexanone. After being recycled through 10 replicate uses, the catalytic activity of the $\mathrm{MnO}_{x}-400$ catalyst was unchanged, demonstrating its good stability.

(C) 2016, Dalian Institute of Chemical Physics, Chinese Academy of Sciences. Published by Elsevier B.V. All rights reserved.
\end{abstract}

\section{Introduction}

The selective liquid phase oxidation of cyclic hydrocarbons is one of the most widely used industrial processes producing oxygenates [1]. Because of the importance of cyclohexanol (A) and cyclohexanone $(\mathrm{K})$ in the production of adipic acid and caprolactam, compounds that in turn are used in the manufacture of nylon- 6 and nylon- 6,6 polymers, the selective oxidation

\footnotetext{
* Corresponding author. Tel: +86-21-64252827; Fax: +86-21-64252923; E-mail: gzhlu@ecust.edu.cn

\# Corresponding author. Tel/Fax: +86-21-64252923; E-mail: zhanwc@ecust.edu.cn

This work was supported by the National Basic Research Program of China (973 Program, 2010CB732300) and the National Natural Science Foundation of China (21103048).

DOI: 10.1016/S1872-2067(15)60983-4 | http://www.sciencedirect.com/science/journal/18722067 | Chin. J. Catal., Vol. 37, No. 1, January 2016
} 
of cyclohexane has become a very important reaction $[2,3]$. In general, there is the trade-off between selectivity and high conversion in hydrocarbon liquid phase oxidation reactions. Thus, conditions generating low conversions (less than 5\%) are generally preferable as a means of preventing over-oxidation to form undesired by-products [4-6]. The greatest challenge associated with conventional industrial processes for cyclohexane oxidation is therefore the inherent difficulty in controlling the selectivity for the target products while obtaining a high conversion [7].

To date, a large number of catalysts have been reported for the oxidation of cyclohexane, such as metalloporphyrins $[8,9]$, metal oxides [10-12], molecular sieves [13-16], carbon nanotubes $[17,18]$, metal-organic frameworks materials $[19,20]$, and small organic molecules [21]. Recently, polyoxometalate-based organic-inorganic hybrids demonstrated superior catalytic activity, producing a $29.4 \%$ yield of $\mathrm{KA}$ oil using $\mathrm{H}_{2} \mathrm{O}_{2}$ as the oxidant with acetonitrile as the solvent [22]. This same work also investigated changing the structure of the ionic liquid (IL) cation and obtained homogeneous catalysts having the structure $\left[\mathrm{MimC}_{4}\right]_{5} \mathrm{PMoV}_{2}$ IL-cation. Using this catalyst, a $28.5 \%$ yield of KA oil was obtained from the cyclohexane oxidation. However, a homogeneous catalyst such as this cannot be separated from the reaction mixture and recycled. Therefore, significant research work has been devoted to the development of heterogeneous catalysts for the selective oxidation of cyclohexane as substitutes for conventional homogeneous catalysts.

Iglesia et al. [23] reported that Mn species in MnAPO materials can serve as active sites during cyclohexane oxidation when using $\mathrm{O}_{2}$ as the oxidant. $\mathrm{Xu}$ et al. [24] also studied the catalytic activity of MnAPO materials with regard to cyclohexane oxidation, and reported $3.7 \%$ conversion of cyclohexane and $64.5 \%$ selectivity for KA oil. However, the complicated process required to synthesize these catalysts and the uneconomical raw materials limit the potential industrial applications of these materials. Various hetero-mixed oxide catalysts have also been studied for the oxidation of cyclohexane, and $\mathrm{WO}_{3} / \mathrm{V}_{2} \mathrm{O}_{5}$ has exhibited high catalytic activity with $\mathrm{H}_{2} \mathrm{O}_{2}$ as the oxidant [11]. Unfortunately, this approach suffers from the toxicity of the vanadium-based catalyst, and so effective, environmentally friendly, inexpensive and safe catalysts for the oxidation of cyclohexane are still required.

The catalytic oxidation of cyclohexane with oxygen as the oxidant has also been widely studied because of the inherently environmentally friendly nature of this process, although the resulting cyclohexane conversion is generally lower compared with that obtained with $\mathrm{H}_{2} \mathrm{O}_{2}$ or tert-butyl hydroperoxide (TBHP). Yang et al. [18] proposed that cyclohexane oxidation proceeds through a radical mechanism with $\mathrm{O}_{2}$ as the oxidant. Hence, in some cases, the use of a radical initiator such as $\mathrm{H}_{2} \mathrm{O}_{2}$ or TBHP in the reaction mixture decreases the induction period and increases the conversion of cyclohexane. Chen et al. [25] also added TBHP to a cyclohexane reaction mixture as a free radical initiator to increase both the reaction rate and the conversion of cyclohexane. Recently, hollow sulfated V-doped TS-1 photocatalysts were evaluated for the selective photooxidation of cyclohexane with molecular oxygen and exhibited high effi- ciency (TOF $=2.37 \mathrm{~h}^{-1}$, based on the molar amount of $\mathrm{V}$ sites) and chemoselectivity (cyclohexanone/cyclohexanol molar ratio = 3.46) [26].

Compared with molecular sieves and metal-organic frameworks materials, transition metal oxides are much easier to prepare and to apply in industrial processes. In the present work, we selected a transition metal oxide (manganese oxide) as the catalyst for the solvent-free oxidation of cyclohexane with molecular oxygen because this oxide is inexpensive, readily available, and environmentally friendly. This study investigated the effect of the calcination temperature on the physicochemical properties of manganese oxide catalysts prepared by a precipitation method. Based on the relationship between the calcination temperature and the resulting physicochemical properties and catalytic performance of the manganese oxide catalysts, we attempted to synthesize a highly effective and stable oxide catalyst for the solvent-free oxidation of cyclohexane with molecular oxygen.

\section{Experimental}

\subsection{Synthesis of catalysts}

Manganese oxide catalysts were prepared by a precipitation method using an aqueous $\mathrm{Mn}\left(\mathrm{NO}_{3}\right)_{2}$ solution as the source of $\mathrm{Mn}$. In a typical procedure, a quantity of a $50 \mathrm{wt} \% \mathrm{Mn}\left(\mathrm{NO}_{3}\right)_{2}$ solution was added to a 250-mL three-neck flask followed by the dropwise addition of a aqueous $\mathrm{NaOH}$ solution (1 mol/L) at $60{ }^{\circ} \mathrm{C}$ with stirring until the mixture reached a $\mathrm{pH}$ of 8 . The solution was subsequently held at $60{ }^{\circ} \mathrm{C}$ for $4 \mathrm{~h}$ with stirring during which time its $\mathrm{pH}$ was maintained at 8 by adding the $\mathrm{NaOH}$ solution as required. The solid product was collected by filtration, washed several times with de-ionized water, dried at $120{ }^{\circ} \mathrm{C}$ overnight, and finally calcined in air at either 350, 400, 450 , or $500{ }^{\circ} \mathrm{C}$ for $4 \mathrm{~h}$. The corresponding samples are designated as $\mathrm{MnO}_{x}-350, \mathrm{MnO}_{x}-400, \mathrm{MnO}_{x}-450$, and $\mathrm{MnO}_{x}-500$, respectively.

\subsection{Characterization of catalysts}

X-ray diffraction (XRD) patterns were recorded on a Bruker AXS D8 Focus X-ray diffractometer with $\mathrm{Cu} K_{\alpha}$ radiation $(\lambda=$ $0.15406 \mathrm{~nm}$ ) at a scanning rate of $6 \% / \mathrm{min}$. $\mathrm{N}_{2}$ adsorption-desorption isotherms were acquired on an ASAP 2010 analyzer (Micromeritics) at $-196{ }^{\circ} \mathrm{C}$. Prior to these measurements, all samples were degassed at $300{ }^{\circ} \mathrm{C}$ for $6 \mathrm{~h}$ under vacuum to remove moisture and any volatile impurities. The Brunauer-Emmett-Teller (BET) method was used to calculate the specific surface areas of samples. X-ray photoelectron spectroscopy (XPS) was performed using a Thermo ESCALAB 250 spectrometer with a monochromatized $\mathrm{Al} K_{\alpha} \mathrm{X}$-ray source (1486.6 eV), employing the C $1 s$ (binding energy $284.6 \mathrm{eV}$ ) peak of adventitious carbon as a reference. Thermogravimetry-differential thermal analysis (TG-DTA) was carried out using a PerkinElmer Pyris Diamond instrument together with a WCT-2 thermal analyzer at a rate of $10{ }^{\circ} \mathrm{C} / \mathrm{min}$ in air.

$\mathrm{H}_{2}$ temperature-programmed reduction ( $\left.\mathrm{H}_{2}-\mathrm{TPR}\right)$ profiles 


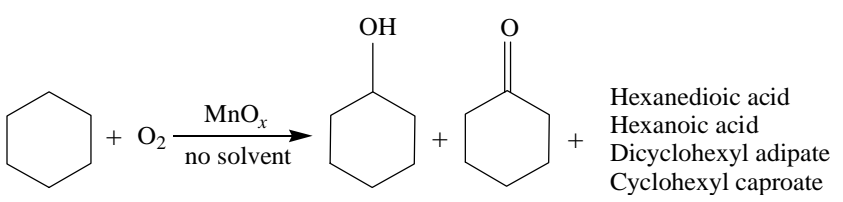

Scheme 1. Oxidation of cyclohexane.

were collected with a PX200 apparatus (Tianjin Pengxiang Technology Co., Ltd., China) equipped with a thermal conductivity detector (TCD). The samples were heated from room temperature to $800{ }^{\circ} \mathrm{C}$ at a rate of $10{ }^{\circ} \mathrm{C} / \mathrm{min}$ under $5 \mathrm{vol} \% \mathrm{H}_{2}$ in $\mathrm{N}_{2}$ ( $\left.40 \mathrm{~mL} / \mathrm{min}\right)$. The hydrogen consumption during this process was measured quantitatively by the TCD. $\mathrm{O}_{2}$ temperature-programmed desorption $\left(\mathrm{O}_{2}\right.$-TPD) was performed using a conventional flow system equipped with a quadrupole mass spectrometer (MS, INFICON IPC400). In these trials, a 200-mg sample was pretreated in $\mathrm{Ar}$ at its original calcination temperature for $1 \mathrm{~h}$. After cooling to $50{ }^{\circ} \mathrm{C}$, the sample was again pretreated in $3 \mathrm{vol} \% \mathrm{O}_{2}$ in $\mathrm{He}(30 \mathrm{~mL} / \mathrm{min})$ for $1 \mathrm{~h}$, after which the system was flushed with Ar for 30 min to sweep residual oxygen from the sample surface. Finally, the sample was heated from 50 to $800{ }^{\circ} \mathrm{C}$ at a heating rate of $10{ }^{\circ} \mathrm{C} / \mathrm{min}$, and the gas released was analyzed online using the MS.

\subsection{Catalytic activity analysis}

The catalytic performance of the catalysts during cyclohexane oxidation was assessed in a 50-mL Teflon-lined stainless steel autoclave while stirring. Molecular oxygen was used as the oxidant without any solvent. In a typical reaction, $8 \mathrm{~mL}$ cyclohexane and $20 \mathrm{mg}$ catalyst were introduced into the reactor. Subsequently, $\mathrm{O}_{2}$ was introduced until the desired initial pressure was obtained at room temperature, after which the reactor was heated to $140{ }^{\circ} \mathrm{C}$ with stirring and these conditions were maintained for $4 \mathrm{~h}$. The post-reaction mixture was analyzed using a PerkinElmer Clarus 500 gas chromatograph equipped with a PE-2 capillary column $(25 \mathrm{~m} \times 0.32 \mathrm{~mm} \times 1.0$ $\mu \mathrm{m})$ and a flame ionization detector (FID). Methylbenzene was used as the internal standard. The main by-products of the reaction were found to be hexanedioic acid, hexanoic acid, di-

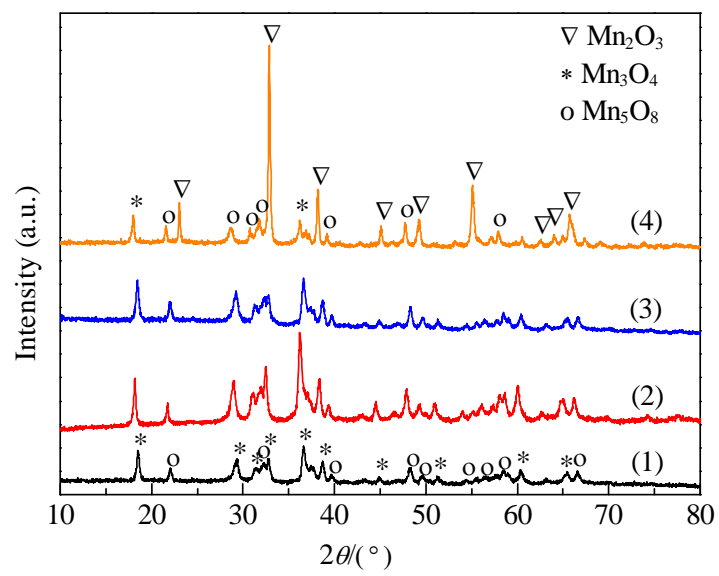

Fig. 1. XRD patterns of $\mathrm{MnO}_{x}-350$ (1), $\mathrm{MnO}_{x}-400$ (2), $\mathrm{MnO}_{x}-450$ (3), and $\mathrm{MnO}_{x}-500$ (4) samples. cyclohexyl adipate, and cyclohexyl caproate (Scheme 1). The concentration of acids in the reaction solution was determined by titration with $0.1 \mathrm{~mol} / \mathrm{L} \mathrm{NaOH}$.

\subsection{Recycling of the catalyst}

Recycling trials were carried out using solely the $\mathrm{MnO}_{x}-400$ catalyst. Following completion of each reaction trial, the catalyst was separated by filtration from the reaction solution, washed with ethanol three times in a glass beaker with stirring, dried at $100{ }^{\circ} \mathrm{C}$ for $6 \mathrm{~h}$, and calcined in air at $400{ }^{\circ} \mathrm{C}$ for $2 \mathrm{~h}$, thus producing the regenerated catalyst. The catalytic performance of the regenerated catalyst together with a supplement of fresh catalyst was then examined using the same reaction procedures applied with the fresh catalyst.

\section{Results and discussion}

\section{1. $X R D$}

The powder XRD patterns of $\mathrm{MnO}_{x}$ samples calcined at different temperatures are shown in Fig. 1. The diffraction peaks of the $\mathrm{MnO}_{x}$-350 sample are consistent with those of hausmannite $\mathrm{Mn}_{3} \mathrm{O}_{4}$ (JCPDS 24-0734) and $\mathrm{Mn}_{5} \mathrm{O}_{8}$ (JCPDS 39-1218). The $\mathrm{Mn}_{3} \mathrm{O}_{4}$ can be considered to have a spinel structure composed of $\mathrm{Mn}^{2+}\left(\mathrm{Mn}^{3+}\right)_{2} \mathrm{O}_{4}$, in which $\mathrm{Mn}^{2+}$ and $\mathrm{Mn}^{3+}$ occupy the tetrahedral and octahedral sites of the structure, respectively [27]. During the calcination process, the octahedral $\mathrm{Mn}^{3+}$ ions in $\mathrm{Mn}_{3} \mathrm{O}_{4}$ are oxidized to $\mathrm{Mn}^{4+}$ preferentially over $\mathrm{Mn}^{2+}$, leading to the formation of $\left(\mathrm{Mn}^{2+}\right)_{2}\left(\mathrm{Mn}^{4+}\right)_{3} \mathrm{O}_{8}$ [28]. In the case of the $\mathrm{MnO}_{x}-400$ and $\mathrm{MnO}_{x}-450$ samples, the intensities of the $\mathrm{Mn}_{3} \mathrm{O}_{4}$ and $\mathrm{Mn}_{5} \mathrm{O}_{8}$ diffraction peaks are markedly strengthened. When the calcination temperature is further increased to $500{ }^{\circ} \mathrm{C}$, $\mathrm{Mn}_{2} \mathrm{O}_{3}$ peaks appear in the pattern of the $\mathrm{MnO}_{x}-500$ sample, and this evidently becomes the main $\mathrm{MnO}_{x}$ phase.

\section{2. $\mathrm{N}_{2}$ adsorption-desorption isotherms}

The $\mathrm{N}_{2}$ adsorption-desorption isotherms and the pore size distributions of samples are shown in Fig. 2. All isotherms ex-

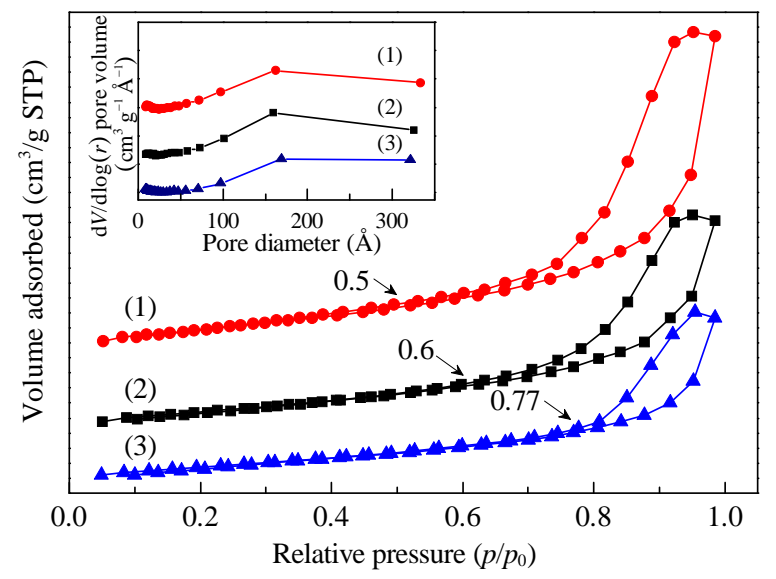

Fig. 2. $\mathrm{N}_{2}$ adsorption-desorption isotherms and pore size distributions (inset) of $\mathrm{MnO}_{x}-350$ (1), $\mathrm{MnO}_{x}-400$ (2), and $\mathrm{MnO}_{x}-500$ (3) samples. 
Table 1

Textural properties of $\mathrm{MnO}_{x}-350, \mathrm{MnO}_{x}-400$, and $\mathrm{MnO}_{x}-500$ samples.

\begin{tabular}{lccc}
\hline Sample & $\begin{array}{c}\text { Surface area } \\
\left(\mathrm{m}^{2} / \mathrm{g}\right)\end{array}$ & $\begin{array}{c}\text { Pore volume } \\
\left(\mathrm{cm}^{3} / \mathrm{g}\right)\end{array}$ & $\begin{array}{c}\text { Aaverage pore } \\
\text { diameter }(\mathrm{nm})\end{array}$ \\
\hline $\mathrm{MnO}_{x}-350$ & 31.4 & 0.13 & 16.3 \\
$\mathrm{MnO}_{x}-400$ & 24.0 & 0.13 & 16.0 \\
$\mathrm{MnO}_{x}-500$ & 20.5 & 0.12 & 17.0 \\
\hline
\end{tabular}

hibit typical V-type shapes as defined by IUPAC. The BET surface areas, average pore diameters, and pore volumes of samples are listed in Table 1 . The BET surface areas of the $\mathrm{MnO}_{x}$ samples are seen to have decreased with increases in the calcination temperature, such that the BET surface areas of the $\mathrm{MnO}_{x}-350$ and $\mathrm{MnO}_{x}-500$ were 31.4 and $20.5 \mathrm{~m}^{2} / \mathrm{g}$, respectively. The pores in these samples are secondary particle-piled pores composed of $\mathrm{MnO}_{x}$, and both the pore volume and pore diameter show only a very slight variation with increasing calcination temperature.

\subsection{XPS results}

The XPS Mn $2 p$ and $01 s$ spectra of the $\mathrm{MnO}_{x}-400$ and $\mathrm{MnO}_{x^{-}}-500$ samples are shown in Fig. 3. The $\mathrm{Mn}$ and $\mathrm{O}$ atom surface concentrations are summarized in Table 2. It can be seen that the surface concentrations of $\mathrm{Mn}$ and $\mathrm{O}$ on the $\mathrm{MnO}_{x}-400$ sample are close to those on the $\mathrm{MnO}_{x}-500$.

The Mn $2 p$ peaks can be deconvoluted to three peaks, and the peaks at binding energy (BE) values of 640.8 and $641.9 \mathrm{eV}$ are assigned to $\mathrm{Mn}^{3+}$ and $\mathrm{Mn}^{4+}$, respectively, while the peak at $643.6 \mathrm{eV}$ is a satellite peak of manganese [29,30]. The $\mathrm{Mn}^{4+} /\left(\mathrm{Mn}^{4+}+\mathrm{Mn}^{3+}\right)$ atomic ratios were calculated from these XPS spectra using XPSPEAK 4.1 and are presented in Table 2. It is evident that the $\mathrm{Mn}^{4+} /\left(\mathrm{Mn}^{4+}+\mathrm{Mn}^{3+}\right)$ ratio of the $\mathrm{MnO}_{x}-400$ sample is higher than that of the $\mathrm{MnO}_{\mathrm{x}}-500$, as result of the appearance of a $\mathrm{Mn}_{2} \mathrm{O}_{3}$ phase in the $\mathrm{MnO}_{x}-500$ (Fig. 1). This phase is responsible for the greater oxidation ability of the $\mathrm{MnO}_{x}-400$ sample compared with the $\mathrm{MnO}_{x}-500$.

The XPS $01 s$ spectra of the $\mathrm{MnO}_{x}-400$ and $\mathrm{MnO}_{x}-500$ samples are also provided in Fig. 3, and here two peaks can be distinguished at 530 and $531 \mathrm{eV}$. The peak at $530 \mathrm{eV}$ is assigned to lattice oxygen $\left(\mathrm{O}^{2-}, \mathrm{O}_{\text {lat }}\right)$, while the peak at $531 \mathrm{eV}$ is attributed

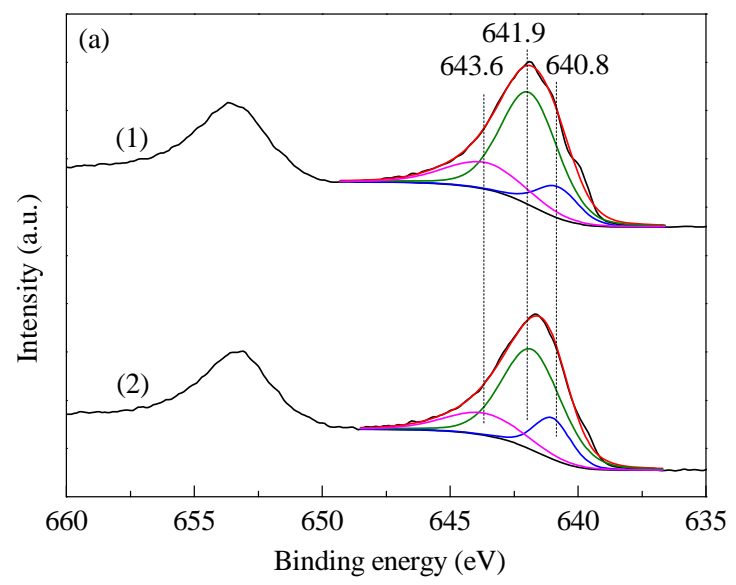

Table 2

Surface atom concentrations on $\mathrm{MnO}_{x}-400$ and $\mathrm{MnO}_{x}-500$ samples as determined by XPS.

\begin{tabular}{|c|c|c|c|c|c|}
\hline \multirow{2}{*}{ Sample } & \multicolumn{3}{|c|}{ Surface atom concentration (\%) } & \multirow{2}{*}{$\begin{array}{c}\mathrm{Mn}^{4+} / \\
\left(\mathrm{Mn}^{4+}+\mathrm{Mn}^{3+}\right)\end{array}$} & \multirow{2}{*}{$\begin{array}{c}\mathrm{O}_{\text {ads }} / \\
\left(\mathrm{O}_{\mathrm{ads}}+\mathrm{O}_{\mathrm{lat}}\right)\end{array}$} \\
\hline & 0 & $\mathrm{Mn}$ & $\mathrm{Mn} / \mathrm{O}$ & & \\
\hline $\mathrm{MnO}_{x}-400$ & 49.9 & 30.6 & 0.61 & 0.25 & 0.30 \\
\hline $\mathrm{MnO}_{x}-500$ & 50.9 & 31.2 & 0.61 & 0.22 & 0.27 \\
\hline
\end{tabular}

to surface oxygen $\left(\mathrm{O}_{\text {ads }}\right)$. These species include surface-adsorbed oxygen and weakly bonded oxygen, such as $\mathrm{O}_{2}{ }^{2-}$ or $\mathrm{O}^{-}$, belonging to defect-oxide or hydroxyl-like surface groups $[31,32]$. The $\mathrm{O}_{\text {ads }} /\left(\mathrm{O}_{\text {ads }}+\mathrm{O}_{\text {lat }}\right)$ ratios of both $\mathrm{MnO}_{x}$ samples were calculated and are given in Table 2 . It is interesting to observe that the $\mathrm{O}_{\text {ads }} /\left(\mathrm{O}_{\text {ads }}+\mathrm{O}_{\text {lat }}\right)$ ratio for the $\mathrm{MnO}_{x}-400$ sample is slightly higher than that for the $\mathrm{MnO}_{x}-500$ sample, indicating that the $\mathrm{MnO}_{x}-400$ has more surface oxygen. This suggests greater oxidation ability for this material compared with the $\mathrm{MnO}_{x}-500$, which in turn favors the selective oxidation of cyclohexane when using $\mathrm{O}_{2}$ as the oxidant.

\section{4. $H_{2}$-TPR results}

The $\mathrm{H}_{2}$-TPR profiles of the $\mathrm{MnO}_{x^{-}} 400$ and $\mathrm{MnO}_{x}-500$ samples are shown in Fig. 4. There are two reduction peaks in the $\mathrm{MnO}_{x}-400$ sample, at 315 and $450{ }^{\circ} \mathrm{C}$, attributed to the reductions $\mathrm{Mn}_{5} \mathrm{O}_{8} \rightarrow \mathrm{Mn}_{3} \mathrm{O}_{4}$ and $\mathrm{Mn}_{3} \mathrm{O}_{4} \rightarrow \mathrm{MnO}$, respectively [33]. With regard to the $\mathrm{MnO}_{x}-500$ sample, four reduction peaks are seen at $161,348,376$, and $500{ }^{\circ} \mathrm{C}$. The small reduction peak at $161{ }^{\circ} \mathrm{C}$ can be attributed to the reduction of $\mathrm{Mn}$ (III) in tetrahedral sites [34,35], while the two overlapped peaks at 348 and $376{ }^{\circ} \mathrm{C}$ are assigned to $\mathrm{Mn}_{5} \mathrm{O}_{8} \rightarrow \mathrm{Mn}_{3} \mathrm{O}_{4}$ and $\mathrm{Mn}_{2} \mathrm{O}_{3} \rightarrow \mathrm{Mn}_{3} \mathrm{O}_{4}$ respectively, and the peak at $500{ }^{\circ} \mathrm{C}$ is assigned to $\mathrm{Mn}_{3} \mathrm{O}_{4} \rightarrow$ MnO [28,36,37]. Compared with the $\mathrm{MnO}_{x}-400$ sample, the main reduction peaks of the $\mathrm{MnO}_{x}-500$ sample are obviously shifted to higher temperatures, showing the lower reducibility of the $\mathrm{MnO}_{x}-500$ sample.

\section{5. $\mathrm{O}_{2}$-TPD results}

Figure 5 presents the $\mathrm{O}_{2}$-TPD profiles of the $\mathrm{MnO}_{x}-400$ and $\mathrm{MnO}_{x}-500$ samples. The $\mathrm{MnO}_{x}-400$ sample exhibits three de-

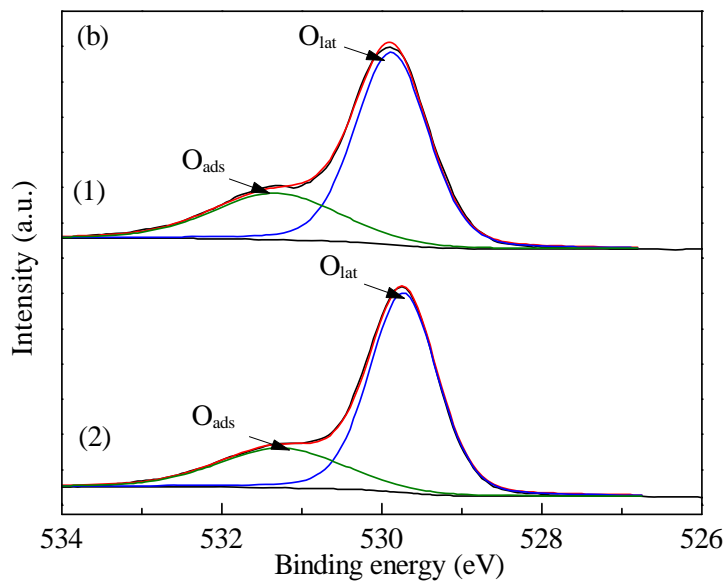

Fig. 3. XPS Mn $2 p$ (a) and $01 s$ (b) spectra of $\mathrm{MnO}_{x}-400$ (1) and $\mathrm{MnO}_{x}-500$ (2) samples. 


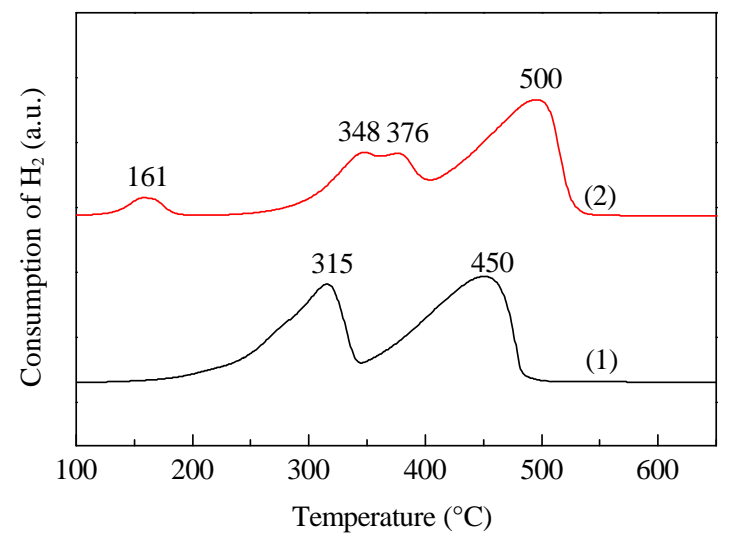

Fig. 4. $\mathrm{H}_{2}$-TPR profiles of $\mathrm{MnO}_{x}-400$ (1) and $\mathrm{MnO}_{x}-500$ (2) samples.

sorption peaks at 487,613 , and $772{ }^{\circ} \mathrm{C}$. The peaks at 487 and $613^{\circ} \mathrm{C}$ are attributed to the desorption of adsorbed and lattice oxygen from $\mathrm{Mn}_{5} \mathrm{O}_{8}$ to $\mathrm{Mn}_{2} \mathrm{O}_{3}$, while the peak at $772{ }^{\circ} \mathrm{C}$ is assigned to the desorption of lattice oxygen from $\mathrm{Mn}_{2} \mathrm{O}_{3}$ to $\mathrm{Mn}_{3} \mathrm{O}_{4}$ [35]. The $\mathrm{MnO}_{x}-500$ sample only generates a weak peak at 540 ${ }^{\circ} \mathrm{C}$ and a strong peak at $844{ }^{\circ} \mathrm{C}$, assigned to the desorptions of adsorbed and lattice oxygen from $\mathrm{Mn}_{2} \mathrm{O}_{3}$ to $\mathrm{Mn}_{3} \mathrm{O}_{4}$ [35,38]. It can be seen that the $\mathrm{MnO}_{x^{-}}-400$ sample has a greater capacity for $\mathrm{O}_{2}$ adsorption compared with the $\mathrm{MnO}_{x}-500$, which could account for the higher reactivity of the $\mathrm{MnO}_{x^{-}} 400$ sample for the selective oxidation of cyclohexane by $\mathrm{O}_{2}$.

\subsection{TG-DTA results}

Figure 6 shows the TG-DTA curves obtained from the $\mathrm{MnO}_{x}-400$ sample before and after the selective oxidation of cyclohexane. Following the reaction, the $\mathrm{MnO}_{x}-400$ sample was collected by filtration, washed several times with deionized water, and dried overnight at $120^{\circ} \mathrm{C}$. The resulting sample was assessed by TG-DTA analysis with the results presented in Fig. 6. It can be seen that the mass of the unreacted $\mathrm{MnO}_{x}-400$ sample exhibits a very slow decrease on heating due to the loss of adsorbed water, and does not generate an obvious exothermic peak in its DTA curve. This result indicates that the $\mathrm{MnO}_{x}-400$ sample is stable when heated to $800^{\circ} \mathrm{C}$. After being used in the reaction, the $\mathrm{MnO}_{x}-400$ sample undergoes a mass loss of $83 \%$ as the temperature is raised to $400{ }^{\circ} \mathrm{C}$, accompanied by a strong

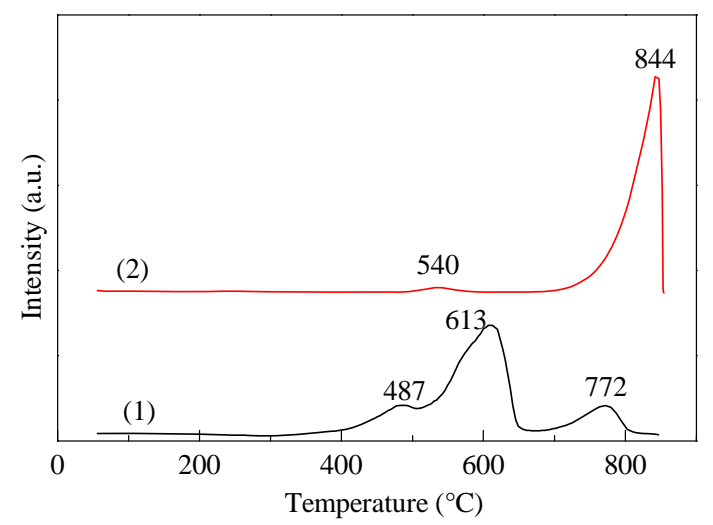

Fig. 5. $\mathrm{O}_{2}$-TPD profiles of $\mathrm{MnO}_{x}-400$ (1) and $\mathrm{MnO}_{x}-500$ (2) samples.

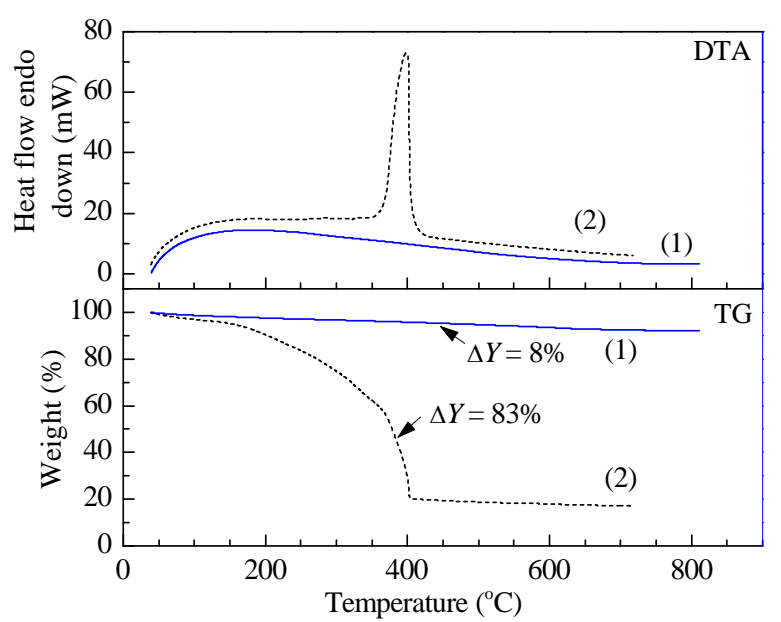

Fig. 6. TG-DTA curves of the $\mathrm{MnO}_{x}-400$ sample before (1) and after (2) the reaction.

exothermic peak at approximately $400{ }^{\circ} \mathrm{C}$, which is due to the combustion of carbon deposited on the $\mathrm{MnO}_{x}-400$ sample during the reaction $[39,40]$.

\subsection{Catalytic performance of $\mathrm{MnO}_{x}$ catalysts}

Table 3 summarizes the catalytic performance of the $\mathrm{MnO}_{x}$ catalysts for the selective oxidation of cyclohexane with $\mathrm{O}_{2}$ as the oxidant. These results show that a $1.2 \%$ conversion of cyclohexane with $92 \%$ total selectivity for KA oil was achieved in the blank test. Using $\mathrm{MnO}_{x}$ as the catalyst, the conversion of cyclohexane was greatly increased while the selectivity for KA markedly decreased. The calcination temperature evidently had a significant effect on the catalytic activity of the $\mathrm{MnO}_{x}$. As the calcination temperature applied to the $\mathrm{MnO}_{x}$ catalysts was increased, the conversion of cyclohexane first increased and then decreased, although the total selectivity for KA oil exhibited a continual gradual increase. As shown in Table 3, when employing the $\mathrm{MnO}_{x}-400$ catalyst, an $8.0 \%$ conversion of cyclohexane was achieved with $62 \%$ total selectivity for KA oil, such that the yield of $\mathrm{KA}$ oil was $5.0 \%$. When using the $\mathrm{MnO}_{x}$ catalyst calcined at $500{ }^{\circ} \mathrm{C}$, the conversion of cyclohexane decreased to $6.1 \%$, but the selectivity for KA oil increased to $75 \%$. Compared with the $\mathrm{MnO}_{x}-400$ catalyst, the $\mathrm{MnO}_{x}-500$ catalyst exhibited a lower surface area and lower concentrations of surface $\mathrm{Mn}^{4+}$ and surface oxygen $\left(\mathrm{O}_{\mathrm{ads}}\right)$, which account for its reduced ability for $\mathrm{O}_{2}$ adsorption and activation and the lower conversion of cyclohexane that it provides. In contrast, the $\mathrm{MnO}_{x}-500$ catalyst's lower ability for $\mathrm{O}_{2}$ adsorption and activation also limited the over-oxidation of cyclohexanol and cyclohexanone, leading to the increase in its selectivity for KA oil. The reported performance of other catalysts intended for the selective oxidation of cyclohexane is also listed in Table 3. When using $\mathrm{O}_{2}$ as the oxidant, the $\mathrm{MnO}_{x}-400$ catalyst showed higher activity for the selective oxidation of cyclohexane than has been reported for Co-TUD- $1, \mathrm{Au} / \mathrm{MgO}$, and $\mathrm{Mn}_{3} \mathrm{O}_{4}$ in the literature [41-43]. However, the yield of KA oil over the $\mathrm{MnO}_{x}-400$ catalyst was much lower than that obtained from a Mn-TUD-1 catalyst when employing TBHP as the oxidant [44]. 
Table 3

Catalytic performance of the $\mathrm{MnO}_{x}$ catalysts for the selective oxidation of cyclohexane with $\mathrm{O}_{2}$.

\begin{tabular}{|c|c|c|c|c|c|c|c|c|}
\hline \multirow{2}{*}{ Catalyst } & \multirow{2}{*}{$\begin{array}{l}\text { Time } \\
(\mathrm{h})\end{array}$} & \multirow{2}{*}{$\begin{array}{c}\text { Atmosphere } \\
(\mathrm{MPa})\end{array}$} & \multirow{2}{*}{$\begin{array}{c}\text { Conversion } \\
(\%)\end{array}$} & \multicolumn{4}{|c|}{ Selectivity (\%) } & \multirow{2}{*}{$\begin{array}{c}\text { Yield of KA oil } \\
(\%)\end{array}$} \\
\hline & & & & Cyclohexanol (A) & Cyclohexanone (K) & KA oil a & Acids ${ }^{b}$ & \\
\hline Blank test & 5 & $\mathrm{O}_{2} / 0.5$ & 1.2 & 43 & 49 & 92 & 4 & 1.1 \\
\hline $\mathrm{MnO}_{x}-400$ & 4 & $\mathrm{~N}_{2} / 0.5$ & - & - & - & - & - & - \\
\hline $\mathrm{MnO}_{x}-350$ & 4 & $\mathrm{O}_{2} / 0.5$ & 7.5 & 30 & 29 & 59 & 8 & 4.4 \\
\hline $\mathrm{MnO}_{x}-400$ & 4 & $\mathrm{O}_{2} / 0.5$ & 8.0 & 32 & 30 & 62 & 6 & 5.0 \\
\hline $\mathrm{MnO}_{x}-450$ & 4 & $\mathrm{O}_{2} / 0.5$ & 6.6 & 34 & 33 & 67 & 7 & 4.4 \\
\hline $\mathrm{MnO}_{x}-500$ & 4 & $\mathrm{O}_{2} / 0.5$ & 6.1 & 38 & 37 & 75 & 8 & 4.6 \\
\hline Co-TUD-1 c [41] & 24 & $8 \% \mathrm{O}_{2} / \mathrm{N}_{2} / 1.5$ & 3.8 & 56 & 31 & 87 & - & 3.3 \\
\hline $\mathrm{Au} / \mathrm{MgO}^{\mathrm{d}}[42]$ & 17 & $\mathrm{O}_{2} / 0.3$ & 5.0 & 50 & 29 & 79 & 19 & 4.0 \\
\hline $\mathrm{Mn}_{3} \mathrm{O}_{4}$ e $[43]$ & 6 & $\mathrm{O}_{2} / 1.0$ & 5.2 & 36 & 27 & 63 & 35 & 3.3 \\
\hline Mn-TUD-1 ${ }^{\mathrm{f}}$ [44] & 24 & TBHP & 13.5 & 24 & 60 & 84 & - & 11.3 \\
\hline
\end{tabular}

Reaction conditions: cyclohexane $4 \mathrm{ml}$, catalyst $20 \mathrm{mg}, 140^{\circ} \mathrm{C}$.

a Cyclohexanol (A) and cyclohexanone (K).

${ }^{\mathrm{b}}$ Adipic acid, glutaric acid, and succinic acid.

c Reaction conditions: cyclohexane $175 \mathrm{mmol}$, cyclohexyl hydroperoxide (radical initiator) $0.05 \mathrm{mmol}$, active metal species $0.1 \mathrm{mmol}, 120^{\circ} \mathrm{C}$.

${ }^{d}$ Reaction conditions: cyclohexane $10 \mathrm{~mL}$, tert-butylhydroperoxy (radical initiator) $0.05 \mathrm{mmol}$, catalyst amount $6 \mathrm{mg}, 140^{\circ} \mathrm{C}$.

e Reaction conditions: cyclohexane $10 \mathrm{~g}$, catalyst amount $0.1 \mathrm{~g}, 140^{\circ} \mathrm{C}$.

${ }^{\mathrm{f}}$ Reaction conditions: cyclohexane $9.8 \mathrm{~g}$, tert-butylhydroperoxy $4.4 \mathrm{~g}$, Mn catalyst $0.1 \mathrm{mmol}, 70^{\circ} \mathrm{C}$.

\subsection{Effect of reaction conditions on the activity of the $\mathrm{MnO}_{\mathrm{x}}-400$ catalyst}

The effects of the reaction temperature, reaction time, and the initial oxygen pressure on the catalytic activity of the $\mathrm{MnO}_{x}-400$ catalyst for the cyclohexane oxidation were evaluated. As shown in Fig. 7(a), with increases in the reaction temperature from 120 to $160{ }^{\circ} \mathrm{C}$, the conversion of cyclohexane gradually increased, while the selectivity for cyclohexanol and cyclohexanone markedly decreased at first, then plateaued. This occurs because the higher reaction temperature enhances the activation of cyclohexane but also promotes the over-oxidation of cyclohexanol and cyclohexanone to esters, which can be detected by GC-MS. Considering both the conversion of cyclohexane and the selectivity for KA oil, it can be seen that the most appropriate reaction temperature is $140{ }^{\circ} \mathrm{C}$.

The effect of the reaction time on the activity of the $\mathrm{MnO}_{x}-400$ catalyst for cyclohexane oxidation is summarized in Fig. 7(b). Increasing the reaction time evidently results in a slight enhancement of the cyclohexane conversion, while the selectivity for cyclohexanol and cyclohexanone decreases gradually because of the over-oxidation of cyclohexanol and cyclohexanone $[45,46]$. The generation of acidic by-products changed only minimally with variations in the reaction time, although esters resulting from over-oxidation of cyclohexanol and cyclohexanone were detected by GC-MS. From these data, the optimal reaction time appears to be $4 \mathrm{~h}$.

Figure 7 (c) shows the effect of the initial $\mathrm{O}_{2}$ pressure on the cyclohexane oxidation over the $\mathrm{MnO}_{x^{-}} 400$ catalyst. The results demonstrate that raising the initial oxygen pressure can enhance both the conversion of cyclohexane and the selectivity for acids, and thus reduce the selectivity for cyclohexanol and cyclohexanone. This phenomenon may be caused by the over-oxidation of cyclohexanol and cyclohexanone under high pressure $\mathrm{O}_{2}$. Taking into account both the conversion of cyclohexane and the selectivity for $\mathrm{KA}$ oil, the optimal initial $\mathrm{O}_{2}$ pressure is evidently $0.5 \mathrm{MPa}$.

\subsection{Repeated use of the $\mathrm{MnO}_{\mathrm{x}}-400$ catalyst}

After the reaction finished, the catalyst was separated by filtration from the reaction solution, washed with ethanol three
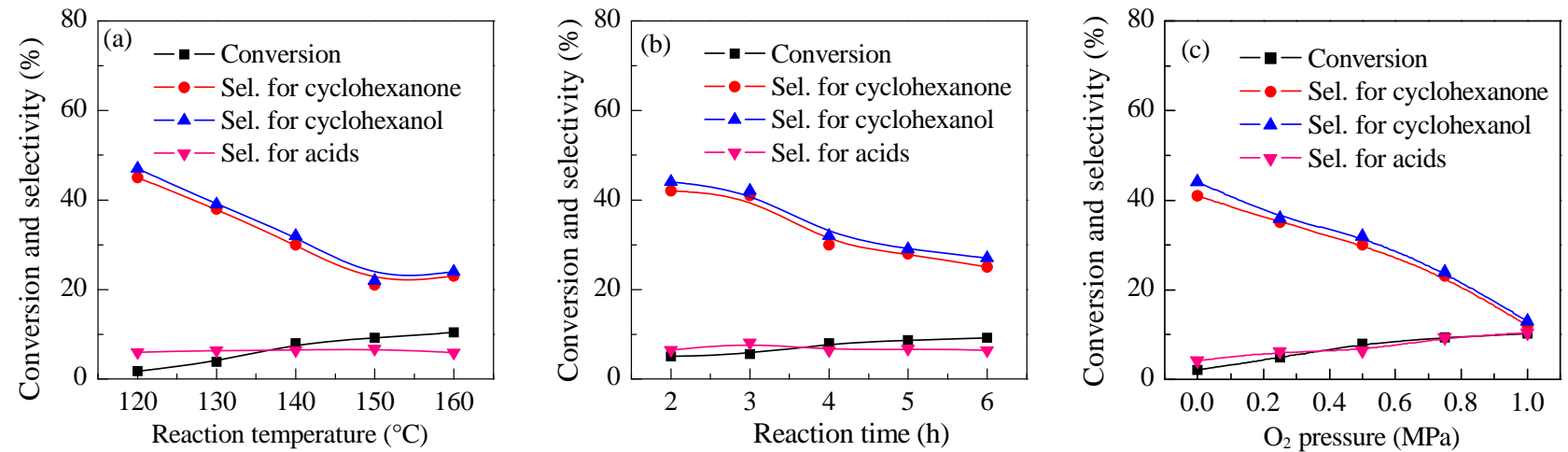

Fig. 7. Effect of the reaction temperature (a), reaction time (b), and initial oxygen pressure (c) on the catalytic activity of Mn $\mathrm{O}_{x}-400$ for cyclohexane oxidation. Reaction conditions: cyclohexane $4 \mathrm{~mL}$, catalyst $20 \mathrm{mg}$; (a) $\mathrm{O}_{2} 0.5 \mathrm{MPa}, 4 \mathrm{~h}$; (b) $\mathrm{O}_{2} 0.5 \mathrm{MPa}, 140{ }^{\circ} \mathrm{C}$; (c) $140{ }^{\circ} \mathrm{C}, 4 \mathrm{~h}$. 


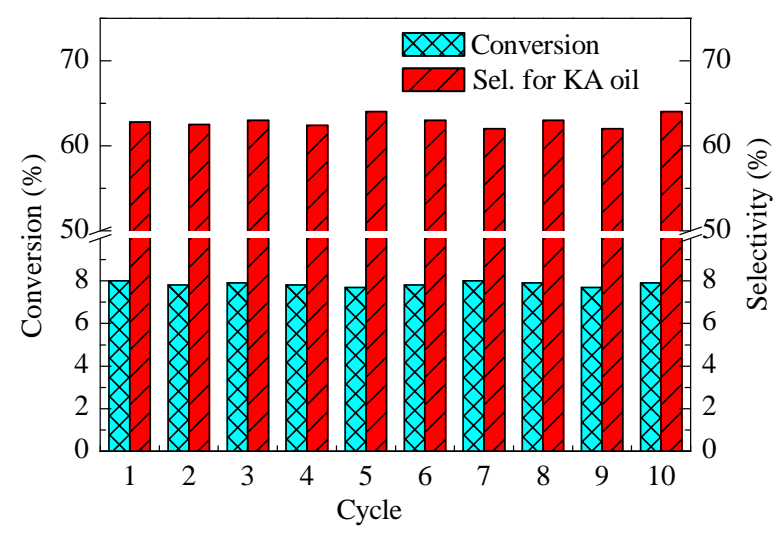

Fig. 8. Effect of recycling on the catalytic activity of $\mathrm{MnO}_{x}-400$ for cyclohexane oxidation.

times, dried at $100{ }^{\circ} \mathrm{C}$ for $6 \mathrm{~h}$, then calcined in air at $400{ }^{\circ} \mathrm{C}$ for 2 h. The catalytic activity of this regenerated $\mathrm{MnO}_{x}-400$ catalyst was subsequently assessed, and the results obtained from 10 such recycling trials are shown in Fig. 8. It can be seen that the conversion of cyclohexane and the selectivity for KA oil are barely changed by the repeated usage. These results indicate that the $\mathrm{MnO}_{x}-400$ catalyst exhibits good stability for the selective oxidation of cyclohexane by $\mathrm{O}_{2}$ in a solvent-free system.

\section{Conclusions}

The effect of calcination temperature on the physicochemical and catalytic properties of $\mathrm{MnO}_{x}$ catalysts prepared by the precipitation method was investigated. These $\mathrm{MnO}_{x}$ catalysts exhibited high catalytic performance during the selective oxidation of cyclohexane with $\mathrm{O}_{2}$ in a solvent-free system. The calcination temperature markedly affected the catalytic activity, such that the catalyst calcined at $400{ }^{\circ} \mathrm{C}$ exhibited the highest activity, giving an 8.0\% cyclohexane conversion and a 5.0\% yield of cyclohexanol and cyclohexanone at $0.5 \mathrm{MPa}$ initial $\mathrm{O}_{2}$ pressure and $140{ }^{\circ} \mathrm{C}$ over $4 \mathrm{~h}$. After 10 reaction cycles, the catalytic activity of the $\mathrm{MnO}_{x^{-}}-400$ catalyst was unchanged, demonstrating that this material is highly stable during the selective oxidation of cyclohexane by $\mathrm{O}_{2}$ in a solvent-free system. Compared with the $\mathrm{MnO}_{x}-500$ catalyst, the $\mathrm{MnO}_{x}-400$ catalyst, consisting of both $\mathrm{Mn}_{3} \mathrm{O}_{4}$ and $\mathrm{Mn}_{5} \mathrm{O}_{8}$, possessed a higher surface area and elevated concentrations of surface adsorbed oxygen and surface $\mathrm{Mn}^{4+}$ ions. These species can promote oxygen mobility, $\mathrm{O}_{2}$ adsorption, and the reducibility of the catalyst, leading to the observed superior catalytic activity of the $\mathrm{MnO}_{x}-400$ catalyst for the selective oxidation of cyclohexane in a solvent-free system.

\section{References}

[1] E. Roduner, W. Kaim, B. Sarkar, V. B. Urlacher, J. Pleiss, R. Gläser, W. D. Einicke, G. A. Sprenger, U. Beifuß, E. Klemm, C. Liebner, H. Hieronymus, S. F. Hsu, B. Plietker, S. Laschat, ChemCatChem, 2013, 5,82 .

[2] A. Sakthivel, P. Selvam, J. Catal., 2002, 211, 134.

[3] L. Gómez-Hortigüela, F. Corà, C. R. A. Catlow, ACS Catal., 2011, 1, 18.

[4] K. Kamata, K. Yonehara, Y. Nakagawa, K. Uehara, N. Mizuno, Nat. Chem., 2010, 2, 478.

[5] K. Weissermel, H. J. Horpe, Industrial Organic Chemistry, 2nd ed., Wiley-VCH, Weinheim, 1993.

[6] A. K. Suresh, M. M. Sharma, T. Sridhar, Ind. Eng. Chem. Res., 2000, $39,3958$.

[7] U. Schuchardt, D. Cardoso, R. Sercheli, R. Pereira, R. S. de Cruz, M. C. Guerreiro, D. Mandelli, E. V. Spinace, E. L. Fires, Appl. Catal. A, 2001, 211, 1.

[8] C. C. Guo, M. F. Chu, Q. Liu, Y. Liu, D. C. Guo, X. Q. Liu, Appl. Catal. A, 2003, 246, 303.

[9] C. C. Guo, G. Huang, X. B. Zhang, D. C. Guo, Appl. Catal. A, 2003, 247, 261.

[10] L. P. Zhou, J. Xu, H. Miao, F. Wang, X. Q. Li, Appl. Catal. A, 2005, 292, 223.

[11] P. R. Makgwane, S. S. Ray, Catal. Commun., 2014, 54, 118.

[12] A. Selvamani, M. Selvaraj, M. Gurulakshmi, R. Ramya, K. Shanthi, J. Nanosci. Nanotechnol., 2014, 14, 2864.

[13] R. Zhao, Y. Q. Wang, Y. L. Guo, Y. Guo, X. H. Liu, Z. G. Zhang, Y. S. Wang, W. C Zhan, G. Z. Lu, Green Chem., 2006, 8, 459.

[14] W. C. Zhan, G. Z. Lu, Y. L. Guo, Y. Guo, Y. Q. Wang, Y. S. Wang, Z. G.

\section{Graphical Abstract}

Chin. J. Catal., 2016, 37: 184-192 doi: 10.1016/S1872-2067(15)60983-4

\section{Solvent-free selective oxidation of cyclohexane with molecular oxygen over manganese oxides: Effect of the calcination temperature}

Mingzhou Wu, Wangcheng Zhan *, Yun Guo, Yunsong Wang, Yanglong Guo, Xueqing Gong, Li Wang, Guanzhong Lu * East China University of Science and Technology

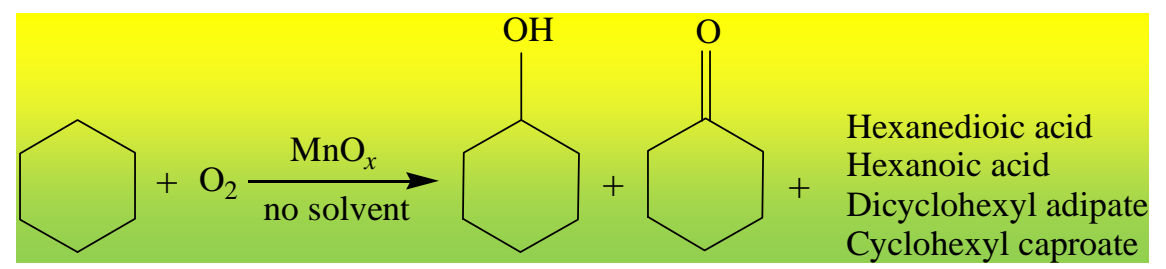

$\mathrm{MnO}_{x}$ exhibited high catalytic activity and excellent stability during cyclohexane oxidation with molecular oxygen. The $\mathrm{MnO}_{x}$ phase state, as determined by the calcination temperature, had a crucial effect on its catalytic activity. 
Zhang, X. H. Liu, J. Rare Earths, 2008, 26, 515.

[15] J. Li, Y. Shi, L. Xu, G. Z. Lu, Ind. Eng. Chem. Res., 2010, 49, 5392.

[16] G. Qian, D. Ji, G. M. Lu, R. Zhao, Y. X. Qi, J. S. Suo, J. Catal., 2005, 232, 378.

[17] H. Yu, F. Peng, J. Tan, X. W. Hu, H. J. Wang, J. Yang, W. X. Zheng Angew. Chem. Int. Ed., 2011, 50, 3978.

[18] X. X. Yang, H. Yu, F. Peng, H. J. Wang, ChemSusChem, 2012, 5, 1213.

[19] N. V. Maksimchuk, K. A. Kovalenko, V. P. Fedin, O. A. Kholdeeva, Chem. Commun., 2012, 48, 6812.

[20] J. L. Long, H. L. Liu, S. J. Wu, S. J. Liao, Y. W. Li, ACS Catal., 2013, 3, 647.

[21] Y. C. Zhang, W. L. Dai, G. J. Wu, N. J. Guan, L. D. Li, Chin. J. Catal., 2014, 35, 279.

[22] S. Xue, G. J. Chen, Z. Y. Long, Y. Zhou, J. Wang, RSC Adv., 2015, 5, 19306.

[23] B. Modén, L. Oliviero, J. Dakka, J. G. Santiesteban, E. Iglesia, J. Phys. Chem. B, 2004, 108, 5552 .

[24] L. P. Zhou, J. Xu, H. Miao, X. Q. Li, F. Wang, Catal. Lett., 2005, 99 , 231.

[25] C. Chen, J. Xu, Q. H. Zhang, H. Ma, H. Miao, L. P. Zhou, J. Phys. Chem. C, 2009, 113, 2855.

[26] W. Z. Zhong, T. Qiao, J. Dai, L. Q. Mao, Q. Xu, G. Q. Zou, X. X. Liu, D. L. Yin, F. P. Zhao, J. Catal., 2015, 330, 208.

[27] J. Pike, J. Hanson, L. H. Zhang, S. W. Chan, Chem. Mater., 2007, 19, 5609.

[28] Q. F. Deng, T. Z. Ren, Z. Y. Yuan, React. Kinet. Mech. Catal., 2013 108, 507.
[29] S. J. Yang, C. Z. Wang, J. H. Li, N. Q. Yan, L. Ma, H. Z. Chang, Appl. Catal. B, 2011, 110, 71.

[30] J. H. Chen, M. Q. Shen, X. Q. Wang, G. S. Qi, J. Wang, W. Li, Appl. Catal. B, 2013, 134-135, 251.

[31] X. Y. Wang, K. Qian, L. Dao, Appl. Catal. B, 2009, 86, 166.

[32] H. C. Yao, Y. F. Yu Yao, J. Catal., 1984, 86, 254.

[33] J. Carnö, M. Ferrandon, E. Björnbom, S. Järås, Appl. Catal. A, 1997, $155,265$.

[34] W. M. Wang, Y. N. Yang, J. Y. Zhang, Appl. Catal. A, 1995, 133, 81.

[35] E. R. Stobbe, B. A. de Boer, J. W. Geus, Catal. Today, 1999, 47, 161.

[36] J. Papavasiliou, G. Avgouropoulos, T. Ioannides, J. Catal., 2007, $251,7$.

[37] A. A. Mirzaei, H. R. Shaterian, M. Habibi, G. J. Hutchings, S. H. Taylor, Appl. Catal. A, 2003, 253, 499.

[38] X. Wang, Y. C. Xie, New J. Chem., 2001, 25, 964.

[39] Y. Kobayashi, J. Horiguchi, S. Kobayashi, Y. Yamazaki, K. Omata, D. Nagao, M. Konno, M. Yamada, Appl. Catal. A, 2011, 395, 129.

[40] Y. L. Wang, G. H. Luo, X. Xu, J. J. Xia, Catal. Commun., 2014, 57, 83.

[41] A. Ramanathan, M. S. Hamdy, R. Parton, T. Maschmeyer, J. C. Jansen, U. Hanefeld, Appl. Catal. A, 2009, 355, 78.

[42] M. Conte, X. Liu, D. M. Murphy, K. Whiston, G. J. Hutchings, Phys. Chem. Chem. Phys., 2012, 14, 16279.

[43] G. Q. Zou, W. Z. Zhong, Q. Xu, J. F. Xiao, C. Liu, Y. Q. Li, L. Q. Mao, S. Kirk, D. L. Yin, Catal. Commun., 2015, 58, 46.

[44] R. Maheswari, R. Anand, G. Imran, J. Porous Mater., 2012, 19, 283.

[45] I. Hermans, J. Peeters, P. A. Jacobs, J. Phys. Chem. A, 2008, 112, 1747.

[46] J. Li, X. Li, Y. Shi, D. S. Mao, G. Z. Lu, Catal. Lett., 2010, 137, 180.

\title{
氧化锰催化剂在环己烷无溶剂选择性氧化反应中的活性: 焙烧温度的影响
}

\author{
吴明周，詹望成，郭 耘，王筠松，郭杨龙，龚学庆，王 丽，卢冠忠 ${ }^{*}$ \\ 华东理工大学结构可控先进功能材料及其制备教育部重点实验室和工业催化研究所, 上海200237
}

摘要: 环己醇和环己酮俗称KA油, 是用于制备尼龙材料的己二酸和己内酰胺的重要中间体. 工业上制取环己醇和环己酮 的方法主要为苯酚加氢法、环已烯水合法和环已烷氧化法, 其中环已烷氧化法的应用最为普遍, 包括硼酸氧化法、过氧化 物氧化法和钴盐催化氧化法三种路线. 为获得适宜的环己醇和环己酮选择性, 工业上环己烷氧化单程转化率通常控制在 $5.0 \%$ 以下, 从而使得产物选择性在 $80 \%$ 以上. 因此, 现有环已烷氧化法生产KA油的最大挑战是如何同时获得高环已烷转化 率和高KA油选择性. 迄今, 已有多种催化剂被尝试用于环已烷氧化反应, 包括金属卟啉、金属氧化物、分子篮、碳纳米管 和金属-有机骨架材料等. 由于均相催化剂无法从环己烷氧化反应体系中分离出来, 导致催化剂不能重复利用, 因此多相催 化剂的研究更受青睐. 另外, 由于采用氧气为氧化剂时具有环境友好和更高的原子经济性, 因此氧气选择性氧化环己烷反 应已逐渐成为环已烷氧化法制KA油中最具挑战性的研究. 目前, 氧气为氧化剂时的环已烷转化率通常低于过氧化氢和叔 丁基过氧化氢等为氧化剂时的转化率, 其关键在于适用于固(催化剂)液(环己烷)气(氧化剂)反应体系的高性能催化剂. 本 课题组前期研究了系列金属掺杂分子篮(Ce/AlPO-5, Ce-MCM-41/48和Mg-Cu/SBA-15等)对氧气催化氧化环己烷的反应性 能, 发现无论是稀土还是过渡金属掺杂, 通过影响环己烷氧化反应的自由基产生和反应历程, 可显著提高环己烷转化率或 者KA油的选择性. 基于此, 本文选择原料易得、成本较低和氧化能力强的氧化锰 $\left(\mathrm{MnO}_{x}\right)$ 作为具有强氧化能力的过渡金属 氧化物的代表, 深入研究了 $\mathrm{MnO}_{x}$ 的焙烧温度对其结构和选择性氧化环己烷反应性能的影响, 同时研究了反应条件对催化 剂性能的影响.

结果表明, $400{ }^{\circ} \mathrm{C}$ 焙烧制得的催化剂 $\left(\mathrm{MnO}_{x}-400\right)$ 比 350,450 和 $500{ }^{\circ} \mathrm{C}$ 焙烧制得的催化剂具有更高的活性. 在最佳反应条 件 $\left(140{ }^{\circ} \mathrm{C}, \mathrm{O}_{2}\right.$ 起始压力 $0.5 \mathrm{MPa}$, 反应 $\left.4 \mathrm{~h}\right)$ 下, 使用 $20 \mathrm{mg} \mathrm{MnO}_{x}-400$ 可使环己烷转化率达 $8.0 \%, \mathrm{KA}$ 油得率为 $5.0 \%$. 过高的反 应温度、过长的反应时间和过高的反应压力都会导致产物被过度氧化, KA油选择性降低. 另外, 该催化剂重复使用 10 次, 其 活性没有明显下降, 显示出了很好的稳定性. 表征测试结果表明, $\mathrm{MnO}_{x}$ 催化剂在不同温度焙烧后形成了不同的结晶形态: 焙烧温度小于 $500{ }^{\circ} \mathrm{C}$ 时, 催化剂主要组成为 $\mathrm{Mn}_{3} \mathrm{O}_{4}$ 和 $\mathrm{Mn}_{5} \mathrm{O}_{8}, 500^{\circ} \mathrm{C}$ 时主要为 $\mathrm{Mn}_{3} \mathrm{O}_{4}, \mathrm{Mn}_{5} \mathrm{O}_{8}$ 和 $\mathrm{Mn}_{2} \mathrm{O}_{3}$. 而且随着焙烧温度升 高, $\mathrm{MnO}_{x}$ 催化剂的比表面积逐渐降低. 相比于 $350^{\circ} \mathrm{C}$ 焙烧制得的催化剂, $\mathrm{MnO}_{x}-400$ 催化剂具有更好的结晶形态, 这可能是 造成其活性较好的原因. 而相比于 $\mathrm{MnO}_{x}-400,500{ }^{\circ} \mathrm{C}$ 焙烧制得的催化剂表面 $\mathrm{Mn}^{4+}$ 含量和表面吸附氧含量较低, 使其吸附和 
活化氧能力降低, 从而导致催化剂活性低于 $\mathrm{MnO}_{x}-400$; 但是吸附和活化氧能力的降低有利于减缓反应产物的深度氧化, 因 而KA油的选择性增加.

关键词: 氧化锰; 环己烷选择氧化; 氧气; 焙烧温度; 无溶剂反应

收稿日期: 2015-08-09. 接受日期: 2015-09-22. 出版日期: 2016-01-05.

*通讯联系人. 电话: (021)64252827; 传真: (021)64252923; 电子信箱: gzhlu@ecust.edu.cn

通讯联系人. 电话/传真: (021)64252923; 电子信箱: zhanwc@ecust.edu.cn

基金来源：国家重点基础研究发展计划(2010CB732300); 国家自然科学基金(21103048).

本文的英文电子版由Elsevier出版社在ScienceDirect上出版(http://www.sciencedirect.com/science/journal/18722067). 